\title{
INVESTIGATION OF HEMATOLOGICAL AND BIOCHEMICAL PROFILES OF ANESTROUS ZEBU COWS
}

\author{
K. F. Pariza ${ }^{1}$, J. Alam ${ }^{1 *}$, M. R. Islam², M. M. Hossain ${ }^{3}$ and M. A. Awal ${ }^{1}$ \\ ${ }^{1}$ Department of Anatomy and Histology, Faculty of Veterinary Science, Bangladesh Agricultural University, \\ Mymensingh -2202, Bangladesh \\ ${ }^{2}$ Department of Surgery and Obstetrics, Faculty of Veterinary Science, Bangladesh Agricultural University, \\ Mymensingh -2202, Bangladesh \\ ${ }^{3}$ Department of Anatomy, Histology and Physiology, Faculty of Animal Husbandry and Veterinary Medicine, \\ Sher-e-Bangla Agricultural University, Sher-e-Bangla Nagar, Dhaka-1207, Bangladesh
}

\begin{abstract}
Blood samples from cows with anestrous were collected for hematological, biochemical and humoral immune status analysis. The erythrocyte sedimentation rate (ESR) was higher and hemoglobin (Hb \%) percentage was lower in anestrous cows than normal cycling control cows. The packed cell volume (PCV \%) was lower in anestrous cows compared with the control cows. Total erythrocyte count was not significantly different between two groups of cows. The total leukocyte count was significantly higher in anestrous cows than control cows. The bilirubin concentration was significantly higher in anestrous cows compared with control cows. The mean serum immunoglobulin (IgG) was lower in anestrous cows than control cows. It is suggested that there is no specific hematological and biochemical marker for anestrous in zebu cows.
\end{abstract}

Key words: Anestrous, Blood Profiles, Zebu Cows

\section{INTRODUCTION}

Anestrous in cows is an important hindrance to the dairy farmers (Serur et al., 1982; Albin et al., 1989; Hafez, 1993). It is known that the zebu cows in a tropical or subtropical environment did not increase their metabolism to the same extent when external temperature rises above $73^{\circ} \mathrm{F}$ as the European cattle (Van Heerden, 1963). High temperature affected the latter breed by suppressing estrous and ovulation causing anestrous (Van Heerden, 1963). The incidence of anestrus was 49.91 percent in cows (Serur et al., 1982). The most frequent form of anestrus in cattle was ovarian inactivity and its incidence was $74.73 \%$ in cattle (Serur et al., 1982). The incidence of persistence corpus luteum was greater in cows and it was about $19.86 \%$. The incidence of silent heat was $23.24 \%$ in heifers and $6.82 \%$ in cows (Serur et al., 1982).

Anestrus is the most important reproductive disorders encountered in Bangladesh causing considerable economic loss. Anestrous was the most frequent functional disorder while endometritis was the most common infections (Gonzalez et al, 1996). There is a report that cows had the lowest P, $\mathrm{Zn}$ and Fe, the highest Mn levels and subnormal $\mathrm{Cu}$ level in whole blood (Prasad and Rao et al.1997). Moreover, total protein, cholesterol, glucose, calcium, inorganic phosphorus, sodium, chloride, potassium, alkaline phosphate and SGOT were significantly lower in the anestrous cows than those in the normal cycling counterparts (Arosh et al., 1998). Very limited studies have been conducted to determine the hematological and biochemical parameters of blood in anestrus zebu cows in Bangladesh. Therefore, the present investigation was undertaken to evaluate the hematological and biochemical profiles of anestrous Zebu cows in Bangladesh.

\section{MATERIALS AND METHODS \\ Animal selected}

A total number of 26 lactating multiparous zebu(in title of manuscript, it is mentioned as zebu) cows weighing 220-355 kg were divided into two groups. Cows in group A ( $\mathrm{n}=13)$ were suffering from post-partum anestrus of more than 90 days and all were outpatients at the veterinary clinic, Bangladesh Agricultural University, Mymensingh. Cows in Group-B (control group) ( $\mathrm{n}=13$ ) were cycling lactating multiparous cows of mixed breed selected from Bangladesh Agricultural University dairy farm. The cows in Group A were normally maintained on rice straw, cut and carry grass and limited grazing on roadside and community land. Concentrate derived from milling by-products such as rice polish, wheat bran, and mustard or sesame oil cakes were also fed at the rate of 1-2 kg per 1.5-2.0 liters of milk yield). There ass no system of estrous detection but farmers relied on visible signs of estrous. Control cows were fed concentrate, green grasses and straw. Total feeds and forages were given in two splits per day. 


\section{K. F. Pariza and others}

\section{Blood Sampling}

Five (5) ml blood was collected from each cow by jugular vein puncture using ten (10) ml plastic syringe on first day after examination and every week for three weeks. Half of the blood sample was kept with heparinized saline for routine hematological examination. Rest of the sample was taken in vials for collection of serum. Serum sample was kept at $-20^{\circ} \mathrm{C}$ until analyzed.

\section{Hematological studies}

Erythrocyte sedimentation rate (ESR), packed cell volume (PCV), hemoglobin percentage (Hb\%), total erythrocyte count (TEC), total leukocyte count (TLC) and differential leukocyte count (DLC) were carried out as described by Coffin (1953).

\section{Total Serum Protein Assay}

Total blood protein was measured using Folin-Phenol method. Briefly, a standard curve was made with equilibrated $(200 \mu \mathrm{l}$ distilled water) bovine serum albumin solution $(1 \mathrm{mg} / \mathrm{ml})$ ranging from 0 to $60 \mu$ l. Unknown serum samples $(10 \mu \mathrm{l})$ were taken in separate tubes after similar equilibration. After addition of prepared solution (one $\mathrm{ml}$ ), each tube was incubated in a dark place for 30 minutes at room temperature. The absorbance of standard proteins at $660 \mathrm{nmol}$ using spectrophotometer was plotted against concentration of BSA and concentrations of proteins were extrapolated by putting the value of optical density (OD) in the standard curve.

Serum bilirubin was measured using the standard technique. Briefly, five (5) $\mathrm{ml}$ methanol, one $\mathrm{ml}$ diazo reagent and four $\mathrm{ml}$ diazo blank were taken as blank sample. For unknown serum sample, five ml methanol and one $\mathrm{ml}$ diazo reagent and four $\mathrm{ml} \mathrm{1:10} \mathrm{diluted} \mathrm{serum} \mathrm{were} \mathrm{mixed} \mathrm{thoroughly} \mathrm{and} \mathrm{incubated} \mathrm{for} 30$ minutes at room temperature. The blank was set at $100 \%$ at $540 \mathrm{~nm}$ and the percent $(\%)$ of transmission $(\mathrm{T})$ was read in the unknown sample. The result of percent transmission (\% $\mathrm{T})$ was then converted to $\mathrm{mg} / \mathrm{dl}$.

\section{Measurement of serum immunoglobulin-G (IgG)}

Serum IgG was measured by single radial immunodifussion techniques (Mancini et al.1965) in anestrous and control group of cows. Data were recorded from the serological test and analyzed for the comparison with the control group of cows.

\section{Serum progesterone level}

The mean concentration of the blood progesterone level in cows with anestrous and control group were measured with radioimmuno-assay (RIA). The data were recorded from the serological test and statistical analysis was done for the comparison between anestrous and control group of cows.

\section{RESULTS AND DISCUSSION \\ Hematological findings}

The results on hematological parameters of cows are shown in Table 1. The mean values of ESR were 9.3 \pm 2.6 and $7.5 \pm 1.2 \mathrm{~mm} / 24$ hour in anestrous and control group of cows, respectively. The mean values of ESR were significantly higher in anestrous group compared to the control group of cows $(\mathrm{P}<0.05)$. The mean hemoglobin percentage $(\mathrm{Hb} \%)$ in anestrous group and control group of cows was $10.2 \pm 1.5$ and $13.1 \pm 2.6$, respectively. The $\mathrm{Hb}$ concentration $(\mathrm{Hb} \%)$ was significantly lower in anestrous group $(\mathrm{p}<0.05)$ compared to control group of cows. The mean PCV in anestrous group and control group was $31.3 \pm 5.2$ and $43.2 \pm 7.9$, respectively. Packed cell Volume percentage (PCV \%) in anestrous group of cows was significantly lower than that of control group of cows. The total erythrocyte count (TEC) of anestrous group of cows and control groups cows was $5.5 \pm 1.2$ and $4.5 \pm 1.5 \mathrm{million} / \mu 1$, respectively. The difference in TEC between anestrous and control groups of cows was not significant. The mean total leukocyte count (TLC) in anestrous and control group of cows was $9.3 \pm 5.6$ and $6.5 \pm 1.5$, respectively. The TLC in anestrous group of cows was significantly higher than that in the control group of cows.

\section{Total Serum Protein $(\mathrm{mg} / \mathrm{dl})$}

The mean total serum protein in anestrous and control group of cows were $3.4 \pm 0.8$ and $5.2 \pm 0.8 \mathrm{mg} / \mathrm{dl}$, respectively. It was significantly $(\mathrm{p}<0.001)$ lower in anestrous group of cows than that of control group of cows (Table 2). 


\section{Serum bilirubin:}

The mean concentration of serum bilirubin in anestrous and control group of cows was $0.6 \pm 0.2$ and $0.3 \pm 0.3$, respectively. The mean bilirubin concentration in anestrous group of cows was significantly higher than in control group of cows (Table 2).

Table1. Hematological values of anestrous and control group of cows (Mean $\pm \mathrm{SD}$ )

\begin{tabular}{|lcc|}
\hline Parameters & Anestrous group $(\mathrm{n}=13)$ & Control group $(\mathrm{n}=13)$ \\
\hline ESR mm/24hr & $9.3 \pm 2.6^{*}$ & $7.5 \pm 1.2$ \\
Hb gm.\% & $10.2 \pm 1.5^{*}$ & $13.1 \pm 2.6$ \\
PCV \% & $31.3 \pm 5.2^{* * *}$ & $43.2 \pm 7.9$ \\
TEC million $/ \mu \mathrm{l}$ & $5.5 \pm 1.2$ & $4.5 \pm 1.5$ \\
TLC thousand $/ \mu \mathrm{l}$ & $9.3 \pm 5.6^{* *}$ & $6.5 \pm 1.5$ \\
\hline
\end{tabular}

$* \mathrm{p}<0.05, * * \mathrm{p}<0.01, * * * \mathrm{p}<.0 .001$.

Table 2. Serum total protein, Bilirubin and Immunoglobulin-G (IgG) concentration of anestrous and control group of cows (Mean $\pm \mathrm{SD})$

\begin{tabular}{|lcc|}
\hline Parameters & Anestrous Group $(\mathrm{n}=13)$ & Control Group $(\mathrm{n}=13)$ \\
\hline Serum total protein $(\mathrm{mg} / \mathrm{dl})$ & $3.4 \pm 0.8^{* * *}$ & $5.2 \pm 0.8$ \\
Serum bilirubin $(\mathrm{mg} / \mathrm{dl})$ & $0.5 \pm 0.2^{*}$ & $0.3 \pm 0.3$ \\
Immunoglobulin-G $(\mu \mathrm{g} / \mathrm{dl})$ & $807.7 \pm 170.0^{*}$ & $1222.2 \pm 178.9$ \\
\hline
\end{tabular}

$* \mathrm{p}<0.05, * * * \mathrm{p}<.001$.

\section{Serum Immunoglobulin-G (IgGI)}

The mean concentration of IgG in anestrous and control group of cows was 807.7 \pm 170.0 and $1222.2 \pm 178.9$ $\mu \mathrm{g} / \mathrm{d}$, respectively. The concentration of $\mathrm{IgG}$ in anestrous group of cows was significantly lower than that in control groups of cows (Table 2).

\section{Serum Progesterone level}

The mean concentration of progesterone level in anestrous group was $5.88 \pm 6.84$ and in control group was $11.96 \pm 2.65 \mathrm{nM} / \mathrm{L}$. The differences of concentration of progesterone between anestrous and control group were not significant (Table 3 ).

The erythrocyte sedimentation rate (ESR) is generally higher in anoestrus cows than control cows. Low $\mathrm{Hb} \%$ indicates anemia and its values are significantly low in all anestrous group of cows than control group of cows. The hemoglobin concentration is lower in anoestrus cows (Baki and Rahman, 1981) The animal in the present study were out patients at the veterinary clinic and had been suffering from gastrointestinal parasites causing anemia and hypoprotenemia (Murthy et al., 1975).

Table 3. Bovine serum progesterone concentration ( $\eta \mathrm{M} / \mathrm{L}$, Mean $\pm \mathrm{SD}$ ) measured by radioimmunoassay (RIA) in anestrous and control group of cows $(n=13)$

\begin{tabular}{|lcc|}
\hline Parameter & Anestrous cows & Control cows \\
\hline Progesterone $\left(\mathrm{P}_{4}\right)$ concentration $(\mathrm{nM} / \mathrm{L})$ & $8.25 \pm 1.56$ & $11.96 \pm 2.65$ \\
\hline
\end{tabular}

The concentration in both groups of cows looks similar 


\section{K. F. Pariza and others}

The packed cell volume (PCV \%) was significantly decreased in the anestrous cows compared to the control cows. The PCV \% is the index of anemia (Samad et al., 1978; Baki and Rahman 1981). The total leukocyte count (TLC) was significantly higher in anoestrus cows than in control cows. Possibly bacterial infection was present in the anestrous cows. Indeed chronic microbial infection may cause endometritis that may be responsible for anestrous (Jahan and Myenuddin, 1996). Total serum protein was low in all anestrous cows than control cows. In the present investigation, total serum bilirubin was higher in anestrous cows than control cows. The serum IgG in anestrous group of cows was significantly lower than in control group cows. This could indicate that the lower humoral immunity is a fact in zebu cows. Indeed, humoral immunity is low in cows with anestrous (Dhaliwal et al., 1996; Saini et al., 1999). The progesterone concentration did not show any significant difference in anestrous and control cows.

It is concluded that there is no specific hematological, biological and immunological marker for anestrous in zebu cows and normal cycling cows. Non-specifically erythrocyte sedimentation rate (ESR) values were high in anestrous zebu cows; however the hemoglobin $(\mathrm{Hb})$ and packed cell volume (PCV) values were low. Humoral immune responses are non- specifically lower in all anestrous cows compared with the control cows. There is no difference of progesterone level in anestrous and control cows.

\section{REFERENCES}

1. Albin A, Gustafsson H, Rodriguez Martinez H and Larssor K (1989): Development of day 7 bovine demiembryos transferred into virgin and repeat-heifers. Animal Reproduction Science. 21:161-163.

2. Arosh AJ Kathiresan D, Devanathan, TG., Rajasundaram RC and Rajasekaran, J. (1998). Blood biochemical profiles in normal cyclical and anestrous cows. Indian Journal of Animal Science 68(11): 1154-1156.

3. Baki MA and Rahman MM. (1981). Study on some Hematological values of Diestrus and Anestrous cows of Pabna Breed. Bangladesh Veterinary Journal 21 (1-2): 15-18.

4. Coffin DL (1953). Manual of Veterinary Clinical Pathology $3^{\text {rd }}$ edition, Comstock Publishing Associates .pp. 158-186.

5. Dhaliwal GS, Murray RD, Dobson H, Montgomery J, Ellis WA and Baker JR (1996). Presence of antigen and antibodies in serum and genital discharges of heifers after experimental intrauterine inoculation with Leptospira interrogans serovar hardjo. Research in Veterinary Science 60 (2): 157-162.

6. Gonzalez JL, Gil A and Aguero F (1996). Principal reproductive disorders in 5/8 Holstein X 3/8 Zebu cows. Revista-de- Salud -Anim 18(1): 59-61.

7. Jahan S and Myenuddin M (1996). Haemato-biological changes in repeat breeder cross- bred cows with previous history of retained placenta. Bangladesh Veterinary Journal 30(1-2): 73-75.

8. Hafez ESE (1993). Reproduction in farm animals. $6^{\text {th }}$ edition book, Lea and Rebiger Philadelphia.

9. Mancini G, Garbonara AO and Heremans JF (1965). Immunochemical quantitation of antigens by single Radial Immunodiffusion. Immunochemistry 61(11):235-54.

10. Murthy GVK, Nanjiah RD and Murthy BSK (1975). Bacterial flora of cervical mucus in repeat breeding bovines. Indian Veterinary Journal 51 (4): 264-268.

11. Prasad KSN and Rao SVN (1997). Blood mineral profile of anestrous and repeat breeder crossbred cows-a field study. Indian Journal of Animal Nutrition. 14 (2): 135-137.

12. Saini OPS, Nanda AS, Grewal AS and Singh J (1999). Uterine defense modulation for the treatment of repeat breeding due to infectious endometritis in bovines. Indian Journal of Animal Science 69:5-7.

13. Samad MA, Rahman A and Ali KM (1978). A note on certain blood chemical and hematological values of repeat breeding heifers caused by glandular vulvo vaginitis. Indian Journal of Animal Science 69:5-9.

14. Serur BH, Farrag AA and Gomaa A (1982). Incidence of certain infertility problems among cows and buffaloes in Upper Egypt. Assiut Veterinary Medical Journal 10 (19): 209-214.

15. Van Heerden S (1963). Aspects of Tropical and Subtropical Infertility in Livestock. Animal Health Monograph 5, FAO, Rome, 78. 